\title{
内瘅核患者におけるニトログリセリン軟膏の 最大肛門静止圧に対する影響について
}

\author{
渡辺賢治 渡辺 元治 増田 英樹1 \\ 渡辺医院，日本大学医学部外科学教室第 3 部門1)
}

\begin{abstract}
ニトログリセリン軟亳の最大肛門静止圧に与える影響について検討した. 対象 : 平成 12 年 11 月から平 成 13 年 4 月までに， $0.5 \%$ ニトログリセリン軟膏(以下 $0.5 \%$ GTN 軟高)を投与した 90 例を対象とした. 方法：0.5\% GTN 軟高を肚門部に塗布し, 約 30 分後に最大肛門静止圧を測定. $0.5 \%$ GTN 軟膏投与前後の 最大肛門静止圧を比較検討した。結果：(1) $0.5 \% \mathrm{GTN}$ 軟高投与前の最大肛門静止圧 $110.2 \pm 52.2 \mathrm{mmHg}$ に対し，投与後は $90.7 \pm 41.1 \mathrm{mmHg}$ と有意に低下した $(\mathrm{p}<0.0001)$ 。(2) $0.5 \%$ GTN 軟膏で低下した症例は 最大肛門静止圧 $100 \mathrm{mmHg}$ 以上で有意に多かった $(\mathrm{p}=0.0045)$. (3) 最大肛門静止圧が $100 \mathrm{mmHg}$ 以上の症 例は，未満の症例より有意に圧の低下を認めた $(\mathrm{p}=0.0121)$. 以上より，0.5\% GTN 軟亳の投与は，内痔 核患者において術前の最大肛門静止圧を下げるのに有効である.特に圧の高い症例ではより有効であると 考える.
\end{abstract}

索引用語：ニトログリセリン軟膏, 最大肛門静止圧, 術後疼痛

はじめに

内痔核に対して痔核根治術を施行する際に問題と なることは術後の出血や術後の疼痛管理である. 手 術術式や術後管理の進歩で, 痔核根治術後の疼痛は 緩和されてきているが, 依然, 患者にとって最も不 安に感じる一つであり, 手術にふみきれない要因で もある，したがって痔核根治術において術後の疼痛 という大きなストレスを取り除くことが必要である と思われる.肛門内圧と術後疼痛の関連については, 最大肛門静止圧が正常よりも高い症例のなかに術後 強度疼痛の発生頻度が高いといわれている ${ }^{1)}$. 我々 も術前の最大肛門静止圧が高い症例で有意に術後の 疼痛が強いことを報告した。さらに，術前の最大肘 門静止圧を $100 \mathrm{mmHg}$ 以上と未満で比較したとこ ろ, $100 \mathrm{mmHg}$ 以上の症例で, 有意に術後の疼痛が強 いことも報告した2!。

ニトログリセリン軟膏は内肛門括約筋の緊張をと るといわれており，裂肛の治療目的で使用すること がある ${ }^{3.4)}$.さらにニトログリセリン軟高と痔核根治 術後の疼痛緩和の関連について検討した報告もみら れる5). そこで今回我々は， $0.5 \%$ ニトログリセリン
軟膏 (以下 $0.5 \% \mathrm{GTN}$ 軟膏) を投与することが, 術前 の最大肚門静止圧にどのような影響を与えるか，さ らに術後疼痛の緩和に有効な方法となりえるかどう かについて検討した。

\section{対}

対象は，平成 12 年 11 月から平成 13 年 4 月まで に, 術前に $0.5 \% \mathrm{GTN}$ 軟言を投与した後痔核根治術 を施行した 90 例 (男性 51 例, 女性 39 例, 平均年令 52.9 歳)である. 手術適応は全例 Goligher 分類の III 度以上とした，術前の最大肛門静止圧が $100 \mathrm{mmHg}$ 以上の症例は 49 例, $100 \mathrm{mmHg}$ 未満の症例は 41 例 であった。

\section{方法}

GTN 軟高は，市販されている $2 \%$ GTN 軟高を 0.5 \%に調整し使用した。投与方法は, $0.5 \%$ GTN 軟亳を 約 700mg（ニトログリセリンの量として約 3.5 $\mathrm{mg}$ )を $6 \mathrm{~cm} \times 8 \mathrm{~cm}$ の大きさに切った綿花に伸ばし， 手術創を覆うように肛門部に塗布した。最大肍門静 止压の測定は，コニスバーグ社のカテーテル型圧力 トランスデューサー（Model No.P31）を用いた。被 
験者を左側臥位にして肛門縁よりトランスデュー サーを挿入し，引き抜きで内圧を測定した. 測定は, $0.5 \% \mathrm{GTN}$ 軟亭投与前と投与後の 2 回測定した. 投 与後から测定までの時間は 30 分とし,内圧を測定後 に手術を施行した。投与後から測定までの時間を 30 分としたのは,一般にGTN 軟膏の塗布により, 最大 肛門静止圧は塗布後 5 分で低下し始め, 10 分後にほ ぼ安定した状態になると報告されており ，さらに， 本来の循環器疾患にニトログリセリン $6 \mathrm{mg}$ を投与 した場合, 最高血中濃度到達時間が 30 分である7と の報告があることからである。

我々は, 術前の最大肚門静止圧が $100 \mathrm{mmHg}$ 以上 の症例で有意に術後の疼痛が強いことを報告し た2).そこで次に, 術前の最大肍門静止圧が 100 $\mathrm{mmHg}$ 未満の群 (以下 $\mathrm{A}$ 群) と $100 \mathrm{mmHg}$ 以上の群 (以下 B 群)に分けて, $0.5 \%$ GTN 軟骨投与後の最大 肛門静止圧を比較検討した。また，術後の疼痛に関 しては, 術後 3 時間後の疼痛を「痛くない」,「少し痛 い」,「痛む」,「とても痛い」の 4 段階に分類 L, A 群と $\mathrm{B}$ 群との間で比較検討した。これは, 我々が術 前最大肛門静止圧と術後疼痛について報告しだ2祭 と同じである．当院では全例 $1 \%$ プロカインによる 局所麻酔下に手術を施行しており，麻酔の影響がな くなった時点で比較する必要がある.また術直後と 術後 3 時間後に疼痛の有無にかかわらず「先取り鎮 痛」及び術後の疼痛緩和の目的で全例インドメタシ ン座薬 $50 \mathrm{mg}$ を挿入している. 更に鎮痛剂の内服は 術後 3 時間以降に, 疼痛の有無によって内服をして もらっている. 以上ょり条件を同じにする意味で, 術後 3 時間後の疼痛を比較検討した。

さらに，0.5\% GTN 軟膏投与時の副作用について (1)副作用（なし）(2)副作用（あり）使用可能(3)副作 用（あり）使用不可能に分類，副作用の症状につい ても検討した．副作用の内容については複数回答も 含め検討した．副作用の判定は, 術直前及び入院加 療中随時, 医師及び看護スタッフが患者からの問診 で行った.

\section{䊅果}

\section{1. 最大肛門静止圧に対する $0.5 \%$ GTN 軟膏の効} 果.

$0.5 \% \mathrm{GTN}$ 軟高投与前の最大肚門静止圧は 110.2 $\pm 52.2 \mathrm{mmHg}$ であるのに対して, 投与後の最大肛門
表 1 最大肛門静止圧に対する $0.5 \% \mathrm{GTN}$ 軟亮の効果

\begin{tabular}{cc}
\hline 投与前 & 投与後 \\
$110.2 \pm 52.2 \mathrm{mmHg}$ & \\
& $\mathrm{p}<0.00001$ \\
& \\
\hline
\end{tabular}

静止圧は $90.7 \pm 41.1 \mathrm{mmHg}$ であった． $0.5 \% \mathrm{GTN}$ 軟 高を投与することで，最大肚門静止圧は有意に低下 した (Wilcoxon signed-ranks test $\mathrm{p}<0.0001$ 表 1 ).

\section{A 群と B 群との間での $0.5 \%$ GTN 軟膏投与後 の最大肛門静止圧の比較.}

B 群の 49 症例に対して $0.5 \%$ GTN 軟膏を投与 し，圧が低下した症例は 39 例であった。これに対し て, A 群の 41 症例では $0.5 \%$ GTN 軟膏投与後, 圧が 低下した症例は 21 例，低下しなかった症例は 20 例 であり，B 群で最大肛門静止圧の低下する症例の割 合が有意に高率であった（ $\chi^{2}$ 検定 $\mathrm{p}=0.0045$, 表 $2)$. 次に, $0.5 \% \mathrm{GTN}$ 軟膏投与前後の最大肛門静止圧 を, A 群と B 群との間で比較検討した. B 群では, 投与前の $75.2 \pm 20.8 \%$ であるのに対して, A 群では, 投与前の $85.7 \pm 17.2 \%$ までしか低下せず， B 群の症 例で有意に最大肛門静止圧の低下を認めた（MannWhitney のU 検定 $\mathrm{p}=0.0121$, 表 3).

\section{3. 術後疼痛についての検討}

術後 3 時間後の疼痛の程度はそれぞれ,「痛くな い」 68 例 $(75.6 \%)$,「少し痛い」8例 $(8.9 \%)$,「痛む」 13 例 $(14.4 \%)$ ，「とても痛い」1例（1.1\%) であった (表 4)。A 群 (41 例) とB群 (49 例) とで比較する と, $\mathrm{A}$ 群では,「痛くない」35 例 $(85.4 \%)$,「少し痛い」 3 例 $(7.3 \%)$,「痛む」 2 例 $(4.9 \%)$,「とても痛い」1 例 $(2.4 \%)$ に対し，B群では,「痛くない」33 例 $(67.3$ $\%)$,「少し痛い」5例 (10.3\%),「痛む」11例（22.4 $\%)$,「とても痛い」0例 $(0 \%)$ であり，それぞれの群 の間には有意差は認めなかった。 $\left(\chi^{2}\right.$ 検定, $\mathrm{p}=$ 0.0677 , 表 5)

\section{4. 副作用についての成績}

副作用（なし）は76 例 $(84.4 \%)$. 副作用（あり） 使用可能は 9 例 $(10.0 \%)$. 副作用 (あり) 使用不可 能は 5 例 (5.6\%)であった(表 6). 副作用の内容は, 頭痛 11 件 $(52.4 \%)$ ，肩凝り 4 件 (19.0\%) 頭重感 3 件 $(14.3 \%)$, 嘔気 2 件 $(9.5 \%)$ ，ボーットした感じ 1 件 $(4.8 \%)$ であった. 
表 2 術前の最大肛門静止圧と $0.5 \% \mathrm{GTN}$ 軟膏投与後の最大肛門静止圧の低下

\begin{tabular}{|c|c|c|}
\hline \multirow{2}{*}{$\begin{array}{l}100 \mathrm{mmHg} \text { 未満: } \mathrm{A} \text { 群 } \\
100 \mathrm{mmHg} \text { 以上 } \mathrm{B} \text { 群 }\end{array}$} & \multicolumn{2}{|c|}{$\mathrm{p}=0.0045$} \\
\hline & $\mathrm{A}$ 群 $(\mathrm{n}=41)$ & B 群 $(n=49)$ \\
\hline 0.5\%GTN 軟弯で圧が低下した & 21 例 & 39 例 \\
\hline 0.5\%GTN 軟毫で圧が低下しない & 20 例 & 10 例 \\
\hline
\end{tabular}

表 3 術前の最大肛門静止圧と $0.5 \% \mathrm{GTN}$ 軟膏投与後の最大肛門静止圧低下率

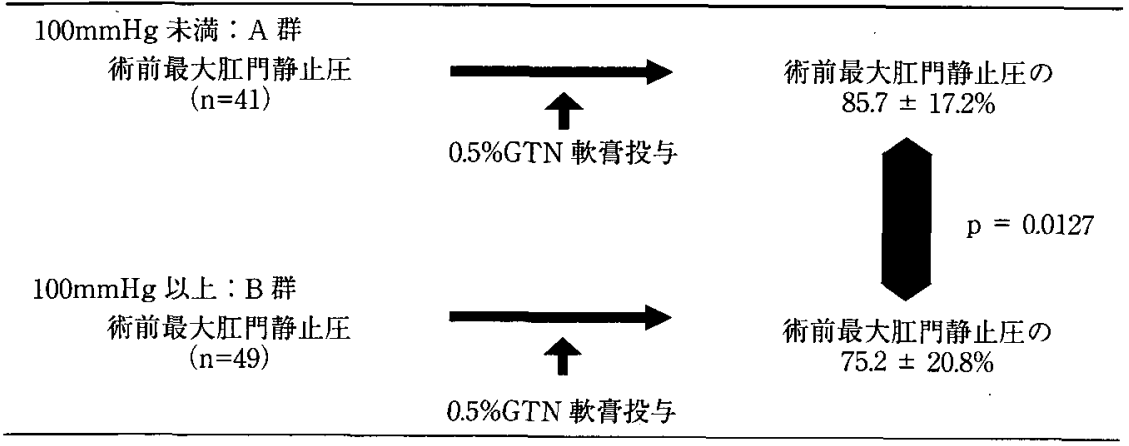

表 5 術前最大肛門静止圧が $\mathrm{A}$ 群と B 群での術後 3 時間後 の疼痛の比較

$100 \mathrm{mmHg}$ 未満：A 群

$100 \mathrm{mmHg}$ 以上：B 群

\begin{tabular}{|c|c|c|}
\hline & \multicolumn{2}{|c|}{ n.s. } \\
\hline & A 群 & B 群 \\
\hline 痛くない & 35 例 $(85.4 \%)$ & 33 例 $(67.3 \%)$ \\
\hline 少し痛い & 3 例 ( $7.3 \%)$ & 5 例 $(10.3 \%)$ \\
\hline 痛む & 2 例 ( $4.9 \%)$ & 11 例 (22.4\%) \\
\hline とても痛い & 1 例 ( $2.4 \%)$ & 0 例 $(0 \%)$ \\
\hline 計 & 41 例 (100\%) & 49 例 (100\%) \\
\hline
\end{tabular}

表 6 副作用について

\begin{tabular}{lr}
\hline 副作用 (なし) & 76 例 $(84.4 \%)$ \\
副作用 (あり) 使用可能 & 9 例 $(10.0 \%)$ \\
副作用 (あり) 使用不可能 & 5 例 $(5.6 \%)$ \\
\hline
\end{tabular}

考察

$0.5 \% \mathrm{GTN}$ 軟膏を術前に肛門部に塗布すること で, 術前の最大肛門静止圧が $110.2 \pm 52.2 \mathrm{mmHg}$ で

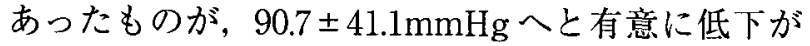
みられた. また, $0.5 \% \mathrm{GTN}$ 軟亮投与後の最大肛門静 止压は投与前の $79.9 \pm 19.8 \%$ まで低下した。これは $0.5 \% \mathrm{GTN}$ 軟高を投与して, 平均 $29 \%$ の最大肛門静 止圧の低下をみたとする報告(6)とはほ同等の成䋶で あった。このことからもニトログリセリン軟高を投 与することで，十分内肛門括的筋を驰緩させること ができると考える。

次に, 術前の最大肛門静止圧が $100 \mathrm{mmHg}$ 以上と 未満との間で， $0.5 \%$ GTN 軟亳投与後の最大肛門静 止圧の低下に差があるかをみた。 $100 \mathrm{mmHg}$ 以上の 群で最大肛門静止圧が低下する症例の割合が有意に 高率であった. また, $0.5 \%$ GTN 軟膏を投与すること で投与前の最大肛門静止圧がどの程度低下するかを 投与前の圧に対する割合（\%) として換算して比較 すると，B 群では $0.5 \% \mathrm{GTN}$ 軟高投与前の $75.2 \pm$ $20.8 \%$ と, A 群と比較して有意に最大肛門静止压が 低下した。開心術後の低心拍出量症候群に対して, 血行動態を改善する目的でニトログリセリン軟膏を 投与した場合，肺動脈楔入圧の低值群より，高值群 でより著明に血行動態の改善を認めたとの報告があ 
る ${ }^{8)}$. 最大肚門静止圧に対しても，より圧の高い症例 でニトログリセリン軟膏が有効であると考える.

術後 3 時間後の疼痛に関しては,「痛くない」と答 えた症例が 68 例 $(75.6 \%)$ であった，以前，0.5\% GTN 軟膏を使用していなかった時期での術後疼痛 を報告した際，術後 3 時間後の疼痛が「痛くない」と 答えた症例は $58.2 \%$ であった2．これと比較する と、「痛くない」と答えた症例が増えた印象がある。 また，0.5\% GTN 軟高を使用していなかった前回の 報告では， $100 \mathrm{mmHg}$ 以上で有意に痛みが強かった のに対して，今回は $100 \mathrm{mmHg}$ 以上と未満との間で 術後の疼痛に有意差を認めなかった。このことから も $0.5 \% \mathrm{GTN}$ 軟高を投与することで, 術後の疼痛を ある程度緩和できるのではないかと考える。しかし ながら，術後の疼痛を比較する際に術後 3 時間後の 疼痛を比較するだけでは不十分であると考えてい る. 今後さらに精細に術後の疼痛については検討し ていく必要があると思われる.

また，ニトログリセリンの持つ血管拡張作用から くる頭痛などの副作用が問題となる．将核根治術後 の疼痛緩和の目的でニトログリセリンを投与し，副 作用としての頭痛に対して消炎鎮痛剂の投与が必要 であったとする報告もある5．当院でも，0.5\% GTN 軟膏投与での副作用の出現率は $15.6 \%$ であり，副作 用により使用できなかったものは $5.6 \%$ であった。 副作用の中で最も多かったのが頭痛であり，52.4\% であった。ニトログリセリン軟膏の投与量に比例し て頭痛の発現頻度や頭痛の程度が重くなり，血槳中 のニトログリセリン濃度との相関を認めるとの報 告 ${ }^{7}$ がある.そこで副作用の対策として 1 回に使用す る $0.5 \% \mathrm{GTN}$ 軟高の投与量の工夫や投与する時期, 例えば排便時の疼痛で内肛門括約筋の緊張や攣縮が おきる時にのみ投与するなどの工夫が必要と思われ る。また，循環器疾患に使用する場合，頭痛発現が 一つの至適用量決定のための指標とされている7 こ とから，症状をみながら早期に患者個々の至適用量 を決定することが必要と考える．また，ニトログリ
セリン軟高の血管搪張作用及び内括約筋弛緩作用 で，術後出血の頻度が増えるのではないかの䀣念が あるが，今のところ術後出血が増えた印象はない。 ただ全身に及ぼす副作用ばかりでなく，創部局所に おける副作用についても今後注意していく必要があ ると考える。

\section{結 論}

$0.5 \% \mathrm{GTN}$ 軟膏を投与することで，有意に最大肛 門静止圧（特に $100 \mathrm{mmHg}$ 以上の症例で）を下げる ことができた。

このことから痔核根治術後の疼痛を緩和する目的 で，0.5\% GTN 軟衰を投与することは有用であると 考える.

副作用としての頭痛等を軽減していく工夫は今後 必要となるであろう。しかし, 現時点においては, 術前の最大肛門静止圧が $100 \mathrm{mmHg}$ 以上の高い症 例で積極的に使用すべきと考える.

\section{文献}

1）辻 順行, 高野正博, 黒水丈次: 庤核術後の疼痛の解析 と対策. 日本大腸肛門病会誌 $52: 519-523,1999$

2）渡辺賢治, 渡辺元治, 増田英樹 : 痔核根治術後の疼痛に ついて一特に術前最大肛門静止圧による術後疼痛の比 較検討一. 日本大腸肛門病学会誌 $53: 241-243,2000$

3) Lund JN, Scholefield JH : A randomised, prospective, double-blind, placebo-controlled trial of glyceryl trinitrate ointment in treatment of anal fissure. The Lancet $349: 11-14,1997$

4）岩垂純一：裂肍の病態と，その治療：最近の知見を中心 に. 日本大腸肛門病会誌 $50: 1089-1095,1997$

5) HJ Wàsvary, J Hain, M Mosed-Vogel, et al : Randomized, prospective, double-blind, placebo-controlled trial of effect of nitroglycerin ointment on pain after hemorrhoidectomy. Dis Colon Rectum 44 : 1069-1073, 2001

6）服部和伸，中島久幸：ニトログリセリン軟亳による裂肛 の治療。臨外 52:521-523, 1997

7）岡島智志, 菱田 仁, 萩原和光ほか：ニトログリセリン 軟高の臨床薬理学的研究. 基礎と臨床 $18: 2489-2504$, 1984

8）大平政人, 麻柄達夫, 能登 佐ほか: ニトログリセリン 軟高の血行動態に及ほす影響一主に開心術後に扮ける 応用一. ICU と CCU $4: 223-230,1980$ 


\title{
Effect of Nitroglycerin Ointment on Preoperative Maximum Anal Canal Resting Pressure in Patients With Hemorrhoids
}

\author{
K. Watanabe ${ }^{1)}$, M. Watanabe ${ }^{1)}$ and H. Masuda ${ }^{2)}$ \\ ${ }^{1)}$ Watanabe Clinic \\ ${ }^{2)}$ The Third Department of Surgery, Nihon University
}

The effect of nitroglycerin ointment on preoperative maximum anal canal resting pressure (PMARP) was evaluated. Patients and Methods : This study included 90 patients with internal hemorrhoids, who underwent hemorrhoidectomy after receiving $0.5 \%$ nitroglycerin ointment, between December 2000 and April 2001. During the preoperative period, PMARP was measured before and after the administration of $0.5 \%$ nitroglycerin ointment. The 90 patients were divided into two groups (the higher group comprised 49 patients with a PMARP of $100 \mathrm{mmHg}$ or higher ; the lower group included 41 patients with a PMARP of lower than 100 mmHg) . Results : 1) The PMARP prior to receiving $0.5 \%$ nitroglycerin ointment was $110.2 \pm 52.2 \mathrm{mmHg}$, which was significantly lower than the PMARP after receiving $0.5 \%$ nitroglycerin ointment $(90.7 \pm 41.1 \mathrm{mmHg})(\mathrm{p}<$ $0.0001)$. 2) In the higher group, the frequency of cases whose PMARP dropped after receiving $0.5 \%$ nitroglycerin ointment was significantly higher than in the lower group. 3) The percentage of PMARP after administration of $0.5 \%$ nitroglycerin ointment in the higher group $(75.2 \pm 20.8 \%)$ was significantly lower than in the lower group ( $85.7 \pm 17.2 \%)$. Conclusion : In patients with internal hemorroids, nitroglycerin ointment was effective in decreasing PMARP, and particularly effective for higher group, and will lead to alleviation of postoperative anal pain for patients with hemorroidectomy. 